\title{
Improving Freezing Tolerance of 'Chambourcin' Grapevines with Exogenous Abscisic Acid
}

\author{
Yi Zhang and Imed Dami ${ }^{1}$ \\ Department of Horticulture and Crop Science, Ohio Agricultural Research \\ and Development Center, The Ohio State University. 1680 Madison Avenue, \\ Wooster, $\mathrm{OH} 44691$
}

Additional index words. phytotoxicity, anthocyanin, periderm formation, leaf senescence, dormancy, water content

\begin{abstract}
The purpose of this study was to develop a protocol to increase freezing tolerance of field-grown 'Chambourcin' grapevines (Vitis spp.) using exogenous abscisic acid (ABA). The specific objectives were to determine the optimum concentration and timing for ABA foliar application in 'Chambourcin' and to evaluate morphological and physiological changes that lead to increased freezing tolerance in response to foliar ABA application. 'Chambourcin' grapevines were treated with a foliar ABA application of concentrations of $0,100,200,300,400,500,600,700$, and $800 \mathrm{mg} \cdot \mathrm{L}^{-1}$ at $50 \%$ fruit set stage to evaluate ABA phytotoxicity under field conditions and identify the optimum concentration. In a subsequent experiment, 'Chambourcin' grapevines were treated with 400 and $600 \mathrm{mg} \cdot \mathrm{L}^{-1}$ of $\mathrm{ABA}$ at different stages of development corresponding to $50 \%$ fruit set, 21 days after $50 \%$ fruit set, $50 \%$ veraison, 20, 30, 40, and 55 days postveraison. ABA concentrations of 700 and $800 \mathrm{mg} \cdot \mathrm{L}^{-1}$ were phytotoxic and caused significant damage to leaves and flowers. Optimum concentrations of ABA did not affect yield components or basic fruit chemical composition, yet it promoted anthocyanin accumulation at harvest. Furthermore, ABA advanced bud dormancy, decreased bud water content, and eventually increased freezing tolerance under simulated freezing tests. The increased freezing tolerance of ABA-treated vines was confirmed by bud injury assessment after a natural freezing event in Jan. 2011. It was also determined that ABA was most effective when applied with an optimum concentration of $400 \mathrm{mg} \cdot \mathrm{L}^{-1} 20$ to 30 days postveraison. It is concluded that exogenous ABA enhanced dormancy and increased freezing tolerance; thus, it has the potential to protect grape cultivars from freezing injury.
\end{abstract}

'Chambourcin' (Vitis spp.) is a FrenchAmerican hybrid cultivar with a higher disease and winter resistance than that in Vitis vinifera L. cultivars and produces quality wine (Read et al., 2004). Thus, it has been successfully grown and well adapted to the midwest and eastern U.S. environment. However, 'Chambourcin' requires a relatively long growing season to ripen its fruit; therefore, the vines are vulnerable to early fall frost in cool seasons and cannot acquire adequate cold acclimation, which results in winter injury. A five-year study with 'Chambourcin' demonstrated that the average fall frost date was $1 \mathrm{~d}$ later than harvest, resulting in inadequate acclimation and subsequent winter injury (Dami et al., 2006).

\footnotetext{
Received for publication 31 July 2012. Accepted for publication 10 Oct. 2012 .

We are thankful for the financial support provided by the Department of Horticulture and Crop Science, Ohio Agricultural Research and Development Center and Lonz Foundation. The abscisic acid sample was provided by Valent Biosciences Co. (Libertyville, IL). We also thank Bruce Williams, Tracey Mechlin, and Natalie Fry for their assistance with the field work.

${ }^{1}$ To whom reprint requests should be addressed; e-maildami.1@osu.edu.
}

$\mathrm{ABA}$ is a phytohormone that plays an important role in plant cold acclimation by facilitating plant acquire freezing tolerance. At a genomic level, it has been found that three unique C-repeat/DRE Binding Factor genes were upregulated by low-temperature treatment or exogenous $\mathrm{ABA}$; and these genes were conservative across both coldtolerant (Vitis riparia) and cold-sensitive (Vitis vinifera) cultivars (Xiao et al., 2006). In addition, it has been reported that a mutant plant insensitive to endogenous ABA had reduced freezing tolerance (Llorente et al., 2000). At a physiological level, it has been reported that the endogenous ABA concentration positively correlates with the cold acclimation process and bud dormancy (Naor et al., 2008; Pagter et al., 2008). Furthermore, ABA treatment has increased freezing tolerance by reduced intracellular water content to avoid ice formation.

Exogenous ABA application to potted grapevines has delayed budburst for spring frost protection but was not effective on fieldgrown grapevines (Hellman et al., 2006). ABA has also been sprayed on table grape clusters during the veraison stage to promote anthocyanin accumulation and thus enhance color development (Peppi et al., 2007). Based on a greenhouse study, ABA has been reported to effectively induce growth cessation, leaf abscission, and increased periderm formation, which all are typically associated with dormancy and cold acclimation (Zhang et al., 2011). It has been reported that ABA treatment $\left(100 \mathrm{mg} \cdot \mathrm{L}^{-1}\right)$ increased dormancy extent of one-year-old buds of 'Chambourcin' (Gu, 2003). However, ABA treatment was applied by immersing the basal end of bud cuttings with ABA solution in a growth chamber (Gu, 2003). Therefore, the response of 'Chambourcin' grapevines to exogenous ABA is not known. The purpose of this study was to develop a protocol to increase freezing tolerance of field-grown 'Chambourcin' grapevines (Vitis spp.) using exogenous ABA. The specific objectives were to determine the optimum concentration and timing for $\mathrm{ABA}$ foliar application in 'Chambourcin' and to evaluate morphological and physiological changes that lead to increased freezing tolerance in response to foliar ABA application.

\section{Materials and Methods}

Plant materials, experimental design, and treatments. Grafted 'Chambourcin' (SeyveVillard $12417 \times$ Seibel 7053) grapevines on rootstock 'Couderc 3309' ( $V$. riparia $\times$ $V$. rupestris) were planted in 1996 at the Research Vineyard in Wooster, $\mathrm{OH}$ (lat. $40^{\circ} 47^{\prime} \mathrm{N}$, long. $81^{\circ} 55^{\prime} \mathrm{W}$, elevation: $311 \mathrm{~m}$ a.s.1., Wooster silt-loam soil) and were used for this study. Vines were spaced $1.25 \times 3 \mathrm{~m}$ $(2722 /$ ha $)$, trained to a high-cordon system (height $=1.83 \mathrm{~m}$ ), and spur-pruned to two buds per spur and 16 buds per meter of cordon followed by shoot and cluster thinning to 13 and 20 per meter of cordon, respectively, before $\mathrm{ABA}$ treatment. In 2009, two experiments were conducted on 'Chambourcin' grapevines to evaluate concentration and timing effect of ABA.

Year 1, Expt. 1: Concentration effect. The purpose of ABA concentration experiment was to evaluate the phytotoxicity of $\mathrm{ABA}$ application under field conditions and confirm the optimum concentration from the greenhouse study (Zhang et al., 2011). The experiment was conducted at 50\% fruit set stage (FS), corresponding to Eichhorn and Lorenz (EL) stage 27 (Eichhorn and Lorenz, 1977) and nine concentrations of ABA solutions $(0,100,200,300,400,500,600,700$, and $800 \mathrm{mg} \cdot \mathrm{L}^{-1}$ ) were applied to vines on a randomized complete block consisting of four blocks with two vines per plot unit.

Year 1, Expt. 2: Timing effect. The purpose of the ABA application timing experiment was to identify the optimum timing for ABA application. Ten treatments were assigned to vines on a randomized complete block consisting of three blocks with five vines per plot unit as follows: 0 (deionized water) and $400 \mathrm{mg} \cdot \mathrm{L}^{-1}$ ABA sprayed at the FS stage (0FS and 4FS, respectively), 0 and $400 \mathrm{mg} \cdot \mathrm{L}^{-1} \mathrm{ABA}$ sprayed at $21 \mathrm{~d}$ after the FS stage (0FS21 and 4FS21, respectively), 0 and $400 \mathrm{mg} \cdot \mathrm{L}^{-1} \mathrm{ABA}$ sprayed at the $50 \%$ veraison stage ( $0 \mathrm{~V}$ and $4 \mathrm{~V}$, respectively), 0 and 400 $\mathrm{mg} \cdot \mathrm{L}^{-1}$ ABA sprayed at $30 \mathrm{~d}$ after the $50 \%$ 
veraison stage $(0 \mathrm{~V} 30$ and $4 \mathrm{~V} 30$, respectively), and multiple application of 0 and $400 \mathrm{mg} \cdot \mathrm{L}^{-1} \mathrm{ABA}$ at all four timing points (0Multiple and 4Multiple, respectively). A surfactant, Tween-20 (Acros Organic, Hampton, $\mathrm{NH}$ ), was added to all treatments at the concentration of $0.05 \%(\mathrm{v} / \mathrm{v})$.

Year 2, Timing effect. In 2010, ABA timing experiment was repeated with adjusted timing points based on the results of the first year and the same vines of Year 1 were used. Seven treatments were assigned to vines on a randomized complete block consisting of four blocks with five vines per plot unit as follows: control (deionized water), 400 and $600 \mathrm{mg} \cdot \mathrm{L}^{-1} \mathrm{ABA}$ sprayed at the $50 \%$ veraison stage ( $4 \mathrm{~V}$ and $6 \mathrm{~V}$, respectively), 400 and $600 \mathrm{mg} \cdot \mathrm{L}^{-1}$ ABA sprayed at $20 \mathrm{~d}$ after the veraison stage (4V20 and 6V20, respectively), and 400 and $600 \mathrm{mg} \cdot \mathrm{L}^{-1} \mathrm{ABA}$ sprayed at $40 \mathrm{~d}$ after the veraison stage (4V40 and 6V40, respectively).

The ABA sample (VBC-30051) was provided by Valent Biosciences Corporation (Libertyville, IL). The active ingredient was $20.0 \%(\mathrm{w} / \mathrm{w})$ S-ABA. Whole vine canopies (leaves and clusters) were sprayed with $\mathrm{ABA}$ solutions to runoff with a 15 -L back sprayer (Model SP0; SP System LLC, Santa Monica, $\mathrm{CA})$ averaging a spray volume of $0.5 \mathrm{~L}$ per vine.

Abscisic acid phytotoxicity. The phytotoxicity of ABA application was evaluated on leaves and clusters. Visual observation of leaf damage followed the method by Zhang et al. (2011) and started $24 \mathrm{~h}$ after ABA application and continued until leaf damage was observed. The percent of damaged leaf area was visually estimated 3 weeks after ABA application and 1 week after ABA-damaged leaves were first detected. Visual observation of fruit damage (small green berries of $1 \mathrm{~cm}$ diameter) was conducted before harvest and the percent of green undeveloped berries was recorded

Vegetative growth and vine size. The measurement of shoot growth started $1 \mathrm{~d}$ after ABA application in the ABA concentration experiment. One shoot was randomly selected per vine before ABA application and marked at $15 \mathrm{~cm}$ from the tip. The distance between the tip and marker was measured three times a week and the shoot growth rate $\left(\mathrm{cm} \cdot \mathrm{d}^{-1}\right)$ was calculated as the total new growth divided by the number of days. The results were averaged between two vines per replicate for each treatment. Vine size (pruning weight) was measured from the $\mathrm{ABA}$ timing experiment in Apr. 2010 and Apr. 2011. All one-year-old canes were weighed for each vine after pruning.

Yield components. Yield components including crop weight per vine, yield per node, cluster number per vine, and 50- or 100-berry weight were collected in both concentration and timing experiments. Cluster weight was calculated based on crop weight per vine divided by cluster number per vine. The berry number per cluster was calculated based on cluster weight divided by 50 - or 100 - berry weight and then multiplied by 50 or 100 , respectively. Grapes were harvested on 21
Oct. 2009 and 18 Oct. 2010. The Ravaz Index was calculated based on the crop weight per vine divided by the pruning weight per vine.

Basic juice analysis. In 2009, a 50-berry sample was collected from each block weekly from veraison through harvest to determine soluble solids, titratable acidity (TA), and $\mathrm{pH}$ in the $\mathrm{ABA}$ timing experiment. One to three berries, representing top, middle, and bottom positions from random clusters, were sampled from each vine and totaling 50 or 100 berries per plot unit. Berries were weighed using an electronic scale (Denver Instrument, Bohemia, NY), and then the berry samples were juiced at room temperature. The juice was transferred to a $50-\mathrm{mL}$ centrifuge tube and centrifuged at $8500 \mathrm{rpm}$ for $5 \mathrm{~min}$ (accuSpin 400; Fisher Scientific, Pittsburgh, PA). A $10-\mathrm{mL}$ supernatant was transferred to the titration work station (PH/EP Titration Workstation Model 350/352) with SAC80 sample change (Denver Instrument, Bihemia, $\mathrm{NY}$ ) to measure $\mathrm{pH}$ and TA. TA was determined by titrating the $10-\mathrm{mL}$ aliquot of juice sample to a $\mathrm{pH} 8.2$ with $0.1 \mathrm{~N} \mathrm{NaOH}$ solution. Soluble solids were measured with a digital refractometer (MISCO, Cleveland, $\mathrm{OH}$ ) and expressed in Brix.

Anthocyanin analysis. Anthocyanin analysis was based on the method by Kleinhenz et al. (2003). At harvest, a 50-berry sample was collected from each treatment replicate and then frozen at $-20{ }^{\circ} \mathrm{C}$ until analysis. The protocol of berry sampling was the same as that of juice analysis. Berries were thawed at room temperature and then crushed into slurry using a hand blender (Whirlpool Corp., Benton Charter Township, MI). Approximately $2 \mathrm{~g}$ slurry was placed into a $50-\mathrm{mL}$ centrifuge tube (Fisher Scientific, Pittsburgh, PA) containing $40 \mathrm{~mL}$ of $1 \% \mathrm{HCl}$ acidified methanol (Fisher Scientific) extraction solvent. Slurry suspensions were allowed to extract for $1 \mathrm{~h}$ at room temperature. Suspensions were then centrifuged for $15 \mathrm{~min}$ at $15,000 \mathrm{rpm}$ and the supernatant was transferred into a $100-\mathrm{mL}$ volumetric flask (NORMAX, New Milford, CT). The pellet was re-extracted using the procedure described previously, and then a third extraction was completed in $30 \mathrm{~min}$ using $15 \mathrm{~mL} 1 \% \mathrm{HCl}$ acidified methanol. The solution was brought to volume with $1 \% \mathrm{HCl}$ acidified methanol and equilibrated by inversion of the flask twice. One milliliter extract was diluted by the addition of $4 \mathrm{~mL} 1 \% \mathrm{HCl}$ acidified methanol; the absorbance of the diluted solution was measured using a spectrophotometer (DU730; Beckman Coulter, Inc., Brea, CA) at $520 \mathrm{~nm}$, the wavelength of maximum absorbance. In 2010, anthocyanin measurement was conducted in the skins only because most anthocyanin is located in berry skins (Jeong et al., 2004). Furthermore, a freeze-dry method was used to facilitate anthocyanin extraction $(\mathrm{Ju}$ and Howard 2003). Thus, anthocyanin concentration was expressed in $\mathrm{mg} \cdot \mathrm{g}^{-1}$ skin dry weight. For that purpose, the berry skins were manually separated from fleshy fruit tissues and freeze-dried using a lyophilizer
(Labconco Corp., Kansas City, MO). The extraction procedure followed the same protocol as in 2009 except the dilution ratio was 1:20 for the absorbance measurement at the last step. The molar absorptivity of anthocyanin was reported by Giusti et al. (1999). The anthocyanin content was expressed in $\mathrm{mg} \mathrm{g}^{-1}$ and calculated as absorbance reading/molar absorptivity $\left(\mathrm{mol} \cdot \mathrm{L}^{-1}\right) \times$ molecular weight $\left(\mathrm{g} \cdot \mathrm{mol}^{-1}\right) \times$ dilution ratio $(1: 5$ in $2009 \mathrm{sam}-$ ples, 1:20 in 2010 samples) $\times 0.1 \mathrm{~L} \times 1000$ (mg.g $\left.{ }^{-1}\right) /$ sample weight $(\mathrm{g})$.

Periderm formation and leaf senescence. Periderm formation and leaf senescence were measured in the timing effect experiment and consisted of counting shoot internodes that changed color from green to tan or brown. In 2009 and 2010, two and five shoots were randomly tagged per treatment-replicate after the last spray application (V30 and V40), respectively. The evaluation was conducted on 30 Oct. 2009 and 15 Nov. 2010 and the numbers of lignified internodes and total internodes nodes were recorded. Periderm formation was expressed as the ratio of number of brown to total number of internodes per shoot.

Leaf senescence was assessed by monitoring chlorophyll content, which was measured using a SPAD-520 chlorophyll meter (Spectrum Technologies, Inc., East Plainfield, IL). Five random measurements were taken on the upper surface of the fifth basal leaf on two shoots per replicate. Weekly measurements were recorded in Wooster from late August (veraison stage) through early Nov. 2009 (killing frost). In 2010, 'Chambourcin' grapevine leaves were infected by downy mildew; thus, no chlorophyll measurement was conducted.

Bud dormancy. Bud dormancy assay was conducted in the timing effect experiment in both years. Two representative canes with a minimum of 12 to 15 lignified internodes were collected from each treatment-replicate and buds on node positions three to seven from each cane were used in the bud dormancy assay. A representative cane consisted of a one-year-old lignified cane with diameter between 0.5 and $1 \mathrm{~cm}$ and internode length between 10 and $12 \mathrm{~cm}$. The periderm color was deep brown. In total, there were 10 nodes per replicate for dormancy assay. Canes were excised into one-node cuttings $\approx 5 \mathrm{~cm}$ long, then inserted into $2.5 \mathrm{~cm} \times 2.5-\mathrm{cm}$ foam medium (Smithers-Oasis, Kent, $\mathrm{OH}$ ) and placed in $55 \mathrm{~cm} \times 25 \mathrm{~cm} \times 7-\mathrm{cm}$ plastic trays (T.O. Plastics, Clearwater, MN) filled with water. Bud dormancy assay followed the protocol by Zhang et al. (2011). Budburst was recorded as EL Stage 5 (Eichhorn and Lorenz, 1977) and monitored three times a week until budburst of all treatments reached at least $50 \%$. Dormancy was estimated as the number of days to $50 \%$ budburst (D50BB) (Wake and Fennell, 2000). In Year 1 , bud samples were collected once on 18 Oct. In Year 2, bud samples were collected monthly from Oct. 2010 through Feb. 2011.

Spring budburst assessment. Budburst assessment was conducted three times a week 
between April and May in 2010 and 2011. The date of $50 \%$ budburst reaching EL Stage 5 (Eichhorn and Lorenz, 1977) was recorded.

Laboratory and field determination of bud freezing tolerance. One representative oneyear-old cane with a minimum of 12 to 15 lignified internodes was collected from each treatment-replicate and buds on node positions three to seven were used. The cane selection criteria were the same as for bud dormancy assay. There were five buds used per replicate with 15 and 20 buds per treatment in 2009 and 2010, respectively. Buds were excised and mounted on thermoelectric modules (MELCOR, Trenton, NJ), which were placed in a Tenney environmental chamber (Thermal Products Solutions, New Columbia, PA). The Tenney temperature was lowered from -2 to $-50{ }^{\circ} \mathrm{C}$ at $4{ }^{\circ} \mathrm{C} \cdot \mathrm{h}^{-1}$. Freezing tolerance of buds was determined using thermal analysis and was expressed as the average lethal temperature exotherm that kills $50 \%$ of the population or LT50 (Wolf and Pool, 1987). In Year 1, $\mathrm{LT}_{50} \mathrm{~S}$ were measured monthly from Sept. 2009 to Apr. 2010 and in 2010; in Year 2, it was repeated from Oct. 2010 to Feb. 2011.

On 22 Jan. 2011, air temperatures dropped to $-19{ }^{\circ} \mathrm{C}$ in Wooster and a bud injury assessment of 'Chambourcin' grapevines was conducted. Ten canes with 10 buds (node positions three to 12) per replicate were collected from all treatments after the freezing event on 31 Jan. 2011. Canes were thawed for $24 \mathrm{~h}$ under room temperature in the laboratory and buds were excised with a razor blade and primary buds were visually assessed whether they were alive (green) or dead (brown). Winter injury was expressed as a percent of dead primary buds.

Bud water content. The water content in buds was measured in the timing effect experiment in 2010. One representative cane was collected from each treatment-replicate $24 \mathrm{~h}$ after ABA application from Oct. 2010 to Feb. 2011, corresponding to the same collection dates for the freezing tests. The selection criteria were the same as for bud dormancy assay and freezing tests. The canes were transported to the laboratory in a cooler filled with ice. Buds on node positions three to seven of each shoot were excised and weighed before and after placing in an oven at $70{ }^{\circ} \mathrm{C}$ for 1 week. Water content was expressed as percent of fresh weight.

Statistical analysis. The data of timing effect experiments were subjected to oneway analysis of variance using Minitab statistical software (Minitab Inc., State College, PA). The model tested for main effects of different treatments. When appropriate, means were separated using least significant difference $(\alpha=0.05)$. The correlation relationship between bud freezing tolerance and water content was determined using Pearson correlation analysis with Minitab statistical software (Minitab Inc.). The data of concentration effect experiment were subjected to linear regression analysis using Minitab statistical software (Minitab Inc.).

\section{Results}

Abscisic acid phytotoxicity. The leaf damage symptoms caused by ABA appeared as red spots and flecks $\approx 0.25 \mathrm{~cm}^{2}$ in size and were similar to those observed in the greenhouse study (Zhang et al., 2011). However, the symptoms appeared 2 to 3 weeks after ABA application, which were much later than those in the greenhouse $(24 \mathrm{~h}$ after application). In the ABA concentration experiment, leaf damage was observed on treated vines with $\mathrm{ABA}$ concentration of $300 \mathrm{mg} \cdot \mathrm{L}^{-1}$ and above. The percent of damaged leaf area was $0.5 \%, 2.8 \%, 4.8 \%, 7.2 \%$,
$12.5 \%$, and $18.2 \%$, which corresponded to ABA concentrations of $300,400,500,600$, 700 , and $800 \mathrm{mg} \cdot \mathrm{L}^{-1}$, respectively. The phytotoxicity of ABA treatment increased linearly with the increase of ABA concentration $\left(P<0.001, R^{2}=0.797\right)$. Only grapevines treated with ABA concentrations of 700 and $800 \mathrm{mg} \cdot \mathrm{L}^{-1}$ had more than $10 \%$ of the leaf area damaged. At harvest, 3\% and 6\% undeveloped green berries were observed in clusters treated with ABA concentrations of 700 and $800 \mathrm{mg} \cdot \mathrm{L}^{-1}$, respectively, but none at lower concentrations. In addition, berry number per cluster averaged 85 in treated vines with ABA concentrations of 700 to 800 $\mathrm{mg} \cdot \mathrm{L}^{-1}$, whereas the average number was 105 berries per cluster in treated vines with ABA concentrations of 0 to $600 \mathrm{mg} \cdot \mathrm{L}^{-1}$ (Table 2). The berry number per cluster decreased linearly with the increase of ABA concentration (Table 2). There was no effect on time of budburst or bud fruitfulness (carryover effect) among all ABA treatments in the next season (data not shown).

Vegetative growth. In the ABA concentration experiment, shoot growth inhibition was observed on grapevines treated with ABA concentrations in the second week after application. Shoot growth inhibition increased with increased ABA concentrations. In fact, control vines averaged shoot growth rate of $1.3 \mathrm{~cm} \cdot \mathrm{d}^{-1}$, similar to that in ABA-treated vines with concentrations of 100 to $500 \mathrm{mg} \cdot \mathrm{L}^{-1}$. However, the growth rate averaged $0.8 \mathrm{~cm} \cdot \mathrm{d}^{-1}$ in ABA-treated vines with the concentrations of 600 to $800 \mathrm{mg} \cdot \mathrm{L}^{-1}$.

Yield components and fruit composition. In the timing experiment, there were no differences among treatments in all yield components. In the concentration experiment, there was no significant linear regression between ABA concentration and all yield components except berry number per cluster (Tables 1 and 2). It was concluded that

Table 1. Timing effect of exogenous abscisic acid (ABA) on yield components in 'Chambourcin' grapevines.

\begin{tabular}{|c|c|c|c|c|c|c|c|c|c|}
\hline Treatment ${ }^{z}$ & $\begin{array}{l}\text { Retained node number } \\
\text { (per meter) }\end{array}$ & $\begin{array}{c}\text { Yield } \\
\text { (kg/vine) }\end{array}$ & $\begin{array}{c}\text { Yield } \\
\text { (g/node) }\end{array}$ & $\begin{array}{l}\text { Cluster number } \\
\text { (per vine) }\end{array}$ & $\begin{array}{l}\text { Cluster } \\
\text { wt (g) }\end{array}$ & $\begin{array}{l}\text { 50/100 berry } \\
\text { wt }(\mathrm{g})^{\mathrm{y}}\end{array}$ & $\begin{array}{l}\text { Berry number } \\
\text { (per cluster) }\end{array}$ & $\begin{array}{l}\text { Vine size } \\
(\mathrm{kg})\end{array}$ & $\begin{array}{l}\text { Ravaz } \\
\text { Index }\end{array}$ \\
\hline & \multicolumn{9}{|c|}{2009} \\
\hline Control & 16 & 4.9 & 308 & 19 & 259 & 130 & 100 & 0.49 & 11 \\
\hline $4 \mathrm{FS}$ & 16 & 5.0 & 315 & 14 & 273 & 130 & 105 & 0.38 & 13 \\
\hline 4FS21 & 16 & 5.5 & 343 & 13 & 241 & 130 & 93 & 0.38 & 15 \\
\hline $4 \mathrm{~V}$ & 16 & 4.2 & 263 & 16 & 227 & 124 & 92 & 0.58 & 10 \\
\hline $4 \mathrm{~V} 30$ & 16 & 5.8 & 360 & 16 & 273 & 129 & 103 & 0.39 & 14 \\
\hline 4Multiple & 16 & 4.3 & 270 & 17 & 259 & 123 & 105 & 0.40 & 12 \\
\hline \multirow[t]{2}{*}{ Significance $^{\mathrm{x}}$} & & NS & NS & NS & NS & NS & NS & NS & NS \\
\hline & \multicolumn{9}{|c|}{2010} \\
\hline Control & 16 & 5.7 & 292 & 30 & 188 & 226 & 83 & 0.37 & 16 \\
\hline $4 \mathrm{~V}$ & 16 & 7.7 & 395 & 34 & 228 & 222 & 103 & 0.37 & 17 \\
\hline $4 \mathrm{~V} 20$ & 16 & 6.8 & 348 & 31 & 220 & 242 & 92 & 0.40 & 17 \\
\hline $4 \mathrm{~V} 40$ & 16 & 6.5 & 330 & 30 & 219 & 232 & 95 & 0.46 & 15 \\
\hline $6 \mathrm{~V}$ & 16 & 6.7 & 344 & 30 & 226 & 228 & 100 & 0.37 & 18 \\
\hline $6 \mathrm{~V} 20$ & 16 & 6.2 & 316 & 30 & 211 & 222 & 95 & 0.34 & 19 \\
\hline $6 \mathrm{~V} 40$ & 16 & 6.5 & 334 & 29 & 228 & 226 & 102 & 0.42 & 16 \\
\hline Significance & & NS & NS & NS & NS & NS & NS & NS & NS \\
\hline
\end{tabular}

${ }^{\mathrm{z}}$ The values of control in 2009 are averages of five control groups, $0 \mathrm{FS}, 0 \mathrm{FS} 21,0 \mathrm{~V}, 0 \mathrm{~V} 30$, and 0 Multiple, which corresponded to 0 mg. $\mathrm{L}^{-1} \mathrm{ABA}$ solution sprayed at the $50 \%$ fruit set stage; $21 \mathrm{~d}$ after the $50 \%$ fruit set stage; $50 \%$ veraison stage; $30 \mathrm{~d}$ after the $50 \%$ veraison stage; and all four timing points, respectively. $4 \mathrm{FS}$, 4FS21, 4V, 4V20, 4V30, and 4V40=ABA concentration of $400 \mathrm{mg} \cdot \mathrm{L}^{-1}$ sprayed at the $50 \%$ fruit set stage; $21 \mathrm{~d}$ after the fruit set stage; $50 \%$ veraison stage; and 20 , 30 , and $40 \mathrm{~d}$ after the $50 \%$ veraison stage, respectively. 4 Multiple $=\mathrm{ABA}$ concentration of $400 \mathrm{mg}$. $\mathrm{L}^{-1}$ sprayed four times (FS, FS21, V, and V30). 6V, 6V20, and $6 \mathrm{~V} 40=\mathrm{ABA}$ concentration of $600 \mathrm{mg} \cdot \mathrm{L}^{-1}$ sprayed at the $50 \%$ veraison stage and 20 and $40 \mathrm{~d}$ after the $50 \%$ veraison stage, respectively.

${ }^{\mathrm{y}}$ In 2009 and 2010, 50-berry and 100 berry sampling were conducted, respectively.

${ }_{\mathrm{N}} \mathrm{N}, * * *$, and $* * *$ Nonsignificant, significant at $P \leq 0.05,0.01$, and 0.001 , respectively. 
ABA treatment did not affect yield components of 'Chambourcin' grapevines in either experiment with the exception of reduced berries per cluster (Tables 1 and 2).

In 2009, there were no differences of Brix, $\mathrm{pH}$, or TA among treatments on each collection date during the biweekly berry sampling for the ABA timing experiment (Table 3). There was no linear regression between $\mathrm{ABA}$ concentration and fruit composition either (Table 4). It was concluded that, based on Brix, $\mathrm{pH}$, and $\mathrm{TA}$, the fruit ripening process was unaffected by ABA. At harvest, there was no difference of fruit chemical compositions among treatments except for TA in 2009 (Table 3). In 2009, multiple application of ABA increased the anthocyanin concentration by $22 \%$ as compared with that in untreated grapevines (Table 3). In 2010, ABA applied at the V20 stage (both 4V20 and 6V20) consistently increased the anthocyanin concentration by $17 \%$ as compared with that in untreated grapevines (Table 3). In the ABA concentration experiment, there was no difference of fruit compositions among treatments.

Periderm formation and leaf senescence. In general, ABA treatments advanced periderm formation in 'Chambourcin' grapevines in both years. In 2009, ABA treatments increased the periderm formation by $100 \%$ compared with that in untreated grapevines. In 2010, ABA treatments increased periderm formation by $30 \%$ compared with that in untreated grapevines; and there was no difference among treatments with $\mathrm{ABA}$ concentrations of 400 and $600 \mathrm{mg} \cdot \mathrm{L}^{-1}$ (Fig. 1). Furthermore, ABA sprayed at $4 \mathrm{~V} 30$ and 4Multiple treatments advanced the progression of leaf senescence (Fig. 2). The leaf senescence, measured as a decline in chlorophyll content, started in all vines between late September and early October (Fig. 2). However, the senescence process was advanced by ABA treatment because the chlorophyll content of ABA-treated leaves was consistently lower than that of untreated leaves by $10 \%$ to $15 \%$ (Fig. 2). In late fall, leaves on ABA-treated grapevines abscised 2 weeks earlier than those on untreated ones.

Bud dormancy. In 2009, bud samples were collected only once on 18 Oct. and the dormancy assay was conducted on the same day. There was no difference of D50BB among all treatments (data not shown). In 2010, bud samples were collected monthly from Oct. 2010 to Feb. 2011. Budburst of ABA-treated vines at V and V20 was delayed by an average of $6 \mathrm{~d}$ from November through February (Fig. 3). The delay of budburst between ABA-treated and untreated vines during the period of November to February indicated that ABA application promoted a deeper dormancy status. There was no difference among treatments with ABA concentrations of 400 and $600 \mathrm{mg} \cdot \mathrm{L}^{-1}$. There was no difference of the date of $50 \%$ budburst among treatments in the next spring seasons.

Laboratory and field determination of freezing tolerance. During the 2009-10 dor-

Table 2. Concentration effect of exogenous abscisic acid (ABA) on yield components in 'Chambourcin' grapevines in 2009.

\begin{tabular}{lccccccc}
\hline $\begin{array}{l}\text { ABA concn } \\
\left(\mathrm{mg} \cdot \mathrm{L}^{-1}\right)\end{array}$ & $\begin{array}{c}\text { Retained } \\
\text { node number } \\
\text { (per meter) }\end{array}$ & $\begin{array}{c}\text { Yield } \\
(\mathrm{kg} / \text { vine })\end{array}$ & $\begin{array}{c}\text { Yield } \\
(\mathrm{g} / \text { node) }\end{array}$ & $\begin{array}{c}\text { Cluster } \\
\text { number } \\
\text { (per vine) }\end{array}$ & $\begin{array}{c}\text { Cluster } \\
\text { wt }(\mathrm{g})\end{array}$ & $\begin{array}{c}\text { 100 berry } \\
\text { wt }(\mathrm{g})\end{array}$ & $\begin{array}{c}\text { Berry } \\
\text { number } \\
\text { (per cluster) }\end{array}$ \\
\hline $0($ Control) & 16 & 5.6 & 287 & 15 & 290 & 267 & 108 \\
100 & 16 & 4.8 & 246 & 13 & 231 & 269 & 109 \\
200 & 16 & 4.1 & 210 & 15 & 268 & 271 & 107 \\
300 & 16 & 3.6 & 184 & 15 & 259 & 264 & 105 \\
400 & 16 & 3.5 & 179 & 14 & 231 & 269 & 103 \\
500 & 16 & 4.1 & 210 & 14 & 290 & 264 & 109 \\
600 & 16 & 4.9 & 251 & 16 & 290 & 269 & 102 \\
700 & 16 & 3.7 & 190 & 12 & 227 & 269 & 88 \\
800 & 16 & 4.1 & 210 & 14 & 218 & 254 & 82 \\
$P^{z}$ & & NS & NS & NS & NS & NS & $* * *$ \\
$R^{2}$ & 16 & & & & 0.370 \\
\hline
\end{tabular}

${ }_{\mathrm{N}} \mathrm{N},{ }^{*}, * *$, and $* * *$, Level of significance for linear regression: nonsignificant, significant at $P \leq 0.05,0.01$, and 0.001 , respectively.

Table 3. Timing effect of exogenous abscisic acid (ABA) on fruit composition in 'Chambourcin' grapevines.

\begin{tabular}{|c|c|c|c|c|}
\hline Treatment $^{\mathrm{z}}$ & ${ }^{\circ}$ Brix & $\mathrm{pH}$ & $\begin{array}{c}\text { Titratable } \\
\text { acidity }\left(\mathrm{g} \cdot \mathrm{L}^{-1}\right)\end{array}$ & Total anthocyanin \\
\hline & & & 2009 & Whole berry (mg. $\mathrm{g}^{-1}$ fresh weight) \\
\hline Control & 21.5 & 3.25 & $11.8 \mathrm{ab}^{\mathrm{y}}$ & $0.93 \mathrm{~b}$ \\
\hline 4FS & 21.5 & 3.27 & $11.6 \mathrm{~b}$ & $1.00 \mathrm{ab}$ \\
\hline $4 \mathrm{FS} 21$ & 20.6 & 3.21 & $11.8 \mathrm{ab}$ & $0.86 \mathrm{~b}$ \\
\hline $4 \mathrm{~V}$ & 21.0 & 3.20 & $13.6 \mathrm{a}$ & $0.98 \mathrm{ab}$ \\
\hline $4 \mathrm{~V} 30$ & 21.0 & 3.24 & $11.5 \mathrm{~b}$ & $0.93 \mathrm{~b}$ \\
\hline 4Multiple & 20.5 & 3.21 & $12.5 \mathrm{ab}$ & $1.15 \mathrm{a}$ \\
\hline \multirow[t]{2}{*}{ Significance $^{\mathrm{x}}$} & NS & NS & $*$ & $*$ \\
\hline & & & 2010 & Berry skin (mg.g ${ }^{-1}$ dry weight) \\
\hline Control & 23.4 & 3.39 & 9.8 & $48 \mathrm{c}$ \\
\hline $4 \mathrm{~V}$ & 23.0 & 3.41 & 9.6 & $50 \mathrm{bc}$ \\
\hline $4 \mathrm{~V} 20$ & 23.2 & 3.37 & 10.1 & $56 \mathrm{a}$ \\
\hline $4 \mathrm{~V} 40$ & 23.6 & 3.42 & 9.8 & $48 \mathrm{c}$ \\
\hline $6 \mathrm{~V}$ & 23.2 & 3.46 & 9.7 & $54 \mathrm{ab}$ \\
\hline $6 \mathrm{~V} 20$ & 22.8 & 3.40 & 9.9 & $56 \mathrm{a}$ \\
\hline $6 \mathrm{~V} 40$ & 23.2 & 3.42 & 9.2 & $54 \mathrm{ab}$ \\
\hline Significance & NS & NS & NS & $* *$ \\
\hline
\end{tabular}

${ }^{\mathrm{z} T h e}$ values of control in 2009 are averages of five control groups, 0FS, 0FS21, 0V, 0V30, and 0Multiple, which corresponded to $0 \mathrm{mg} \cdot \mathrm{L}^{-1} \mathrm{ABA}$ solution sprayed at the $50 \%$ fruit set stage; $21 \mathrm{~d}$ after $50 \%$ fruit set stage; $50 \%$ veraison stage; $30 \mathrm{~d}$ after the $50 \%$ veraison stage; and all four timing points, respectively. $4 \mathrm{FS}$, $4 \mathrm{FS} 21,4 \mathrm{~V}, 4 \mathrm{~V} 20,4 \mathrm{~V} 30$, and $4 \mathrm{~V} 40=\mathrm{ABA}$ concentration of $400 \mathrm{mg} \cdot \mathrm{L}^{-1}$ sprayed at the $50 \%$ fruit set stage; $21 \mathrm{~d}$ after fruit set stage; $50 \%$ veraison stage; 20, 30, and $40 \mathrm{~d}$ after the $50 \%$ veraison stage, respectively. 4 Multiple $=\mathrm{ABA}$ concentration of $400 \mathrm{mg} \cdot \mathrm{L}^{-1}$ sprayed four times (FS, FS21, V, and V30). 6V, 6V20, and $6 \mathrm{~V} 40=\mathrm{ABA}$ concentration of $600 \mathrm{mg} \cdot \mathrm{L}^{-1}$ sprayed at the $50 \%$ veraison stage and 20 and $40 \mathrm{~d}$ after the $50 \%$ veraison stage, respectively.

${ }^{y}$ Means in a column not followed by the same letter are significantly different at $P \leq 0.05$.

${ }_{\mathrm{NS}}, *, * *$, and $* * *$ Nonsignificant, significant at $P \leq 0.05,0.01$, and 0.001 , respectively.

Table 4. Concentration effect of exogenous abscisic acid (ABA) on fruit composition in 'Chambourcin' grapevines in 2009 .

\begin{tabular}{lcccc}
\hline $\begin{array}{l}\text { ABA concn } \\
\left(\mathrm{mg} \cdot \mathrm{L}^{-1}\right)\end{array}$ & ${ }^{\circ}$ Brix & $\mathrm{pH}$ & $\begin{array}{c}\text { Titratable } \\
\text { acidity }\left(\mathrm{g} \cdot \mathrm{L}^{-1}\right)\end{array}$ & $\begin{array}{c}\text { Total anthocyanin } \\
\text { whole berry }\left(\mathrm{mg} \cdot \mathrm{g}^{-1} \text { fresh wt }\right)\end{array}$ \\
\hline $0($ Control) & 21.1 & 3.22 & 12.3 & 0.86 \\
100 & 21.5 & 3.23 & 12.8 & 0.90 \\
200 & 21.7 & 3.21 & 11.4 & 0.71 \\
300 & 21.3 & 3.23 & 12.0 & 0.86 \\
400 & 21.5 & 3.25 & 12.1 & 0.66 \\
500 & 21.3 & 3.23 & 11.8 & 0.70 \\
600 & 21.8 & 3.27 & 11.1 & 0.58 \\
700 & 21.3 & 3.23 & 12.0 & 0.84 \\
800 & 21.3 & 3.23 & 12.1 & 0.72 \\
$P^{\mathrm{z}}$ & NS & NS & NS & NS \\
\hline
\end{tabular}

${ }_{\mathrm{NS}}=$ level of significance for linear regression: nonsignificant.

mant season, $\mathrm{LT}_{50}$ s were not different among treatments during the onset of cold acclimation in Oct. 2009 and during deacclimation in Mar. and Apr. 2010 (Fig. 4A). However,
$\mathrm{LT}_{50} \mathrm{~S}$ of ABA-treated vines at the V30 stage decreased (i.e., freezing tolerance increased) in November, December, January, and February by $3,3.5,2.6$, and $3.3^{\circ} \mathrm{C}$, respectively, 


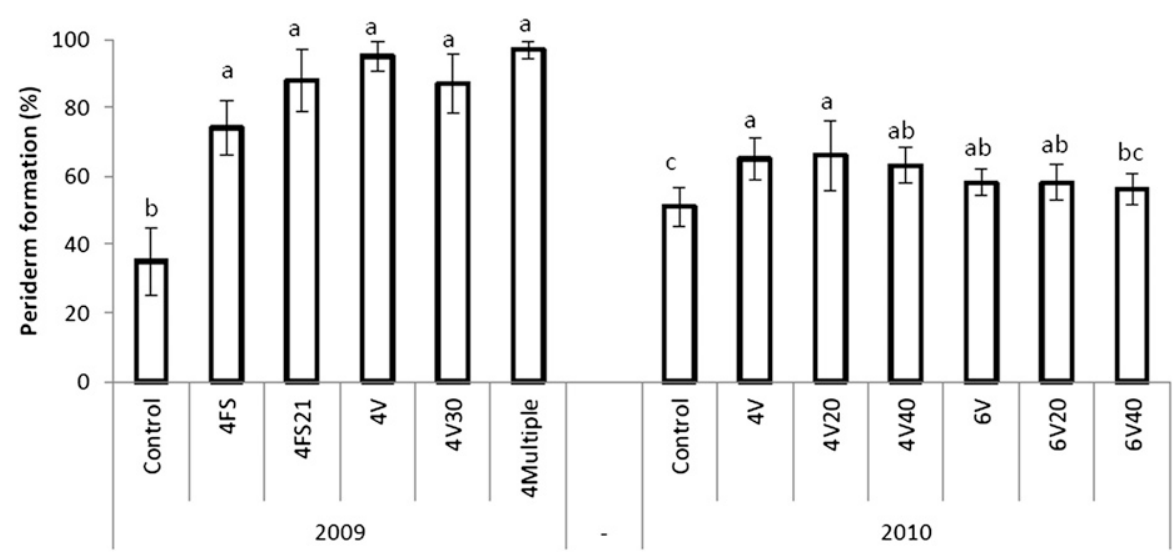

Fig. 1. Effect of exogenous abscisic acid (ABA) on periderm formation in 'Chambourcin' grapevines (40 and $50 \mathrm{~d}$ after ABA application in 2009 and 2010, respectively). For clarity, in 2009, the value of control was the average of five control groups, $0 \mathrm{FS}, 0 \mathrm{FS} 21,0 \mathrm{~V}, 0 \mathrm{~V} 30$, and $0 \mathrm{Multiple}$, corresponding to $0 \mathrm{mg} \cdot \mathrm{L}^{-1}$ ABA solution sprayed at the $50 \%$ fruit set stage, $21 \mathrm{~d}$ after the $50 \%$ fruit set stage, $50 \%$ veraison stage, $30 \mathrm{~d}$ after the $50 \%$ veraison stage, and all four timing points, respectively. Bars with the same letters are not significantly different at $P \leq 0.05$.

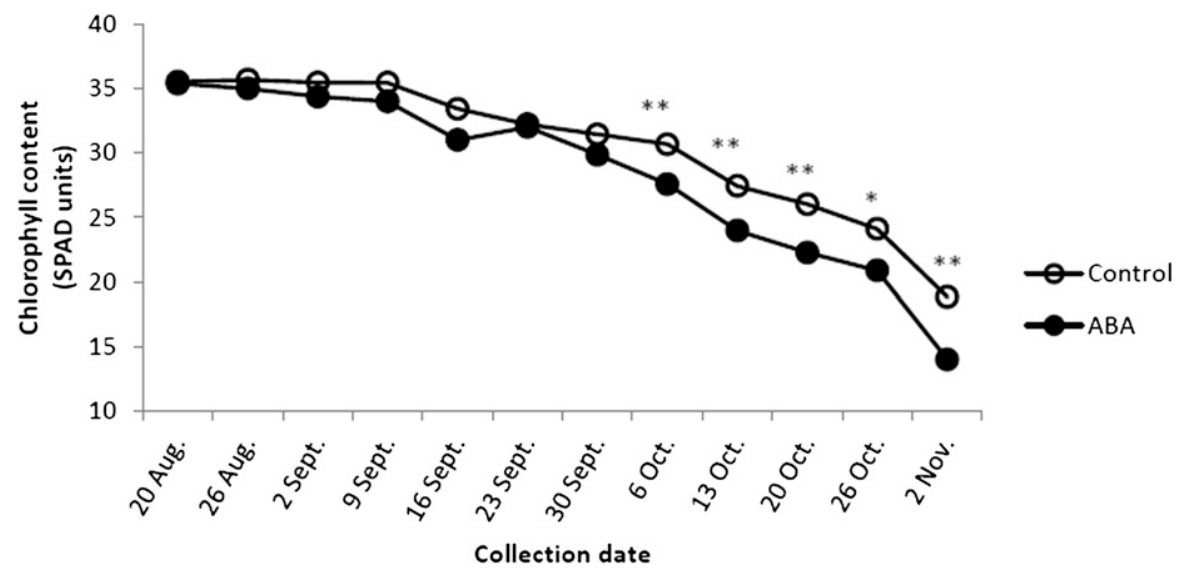

Fig. 2. Chlorophyll content progression in abscisic acid (ABA)-treated and untreated 'Chambourcin' grapevines in 2009. For clarity, only one ABA plot was presented, which was the average of $4 \mathrm{~V} 30$ and 4Multiple treatments, corresponding to ABA application of $400 \mathrm{mg} \cdot \mathrm{L}^{-1}$ sprayed $30 \mathrm{~d}$ after the $50 \%$ veraison stage and all four timing points, respectively. ${ }^{*}, *$, and $* * *$ indicate significance at $P \leq 0.05$, 0.01 , and 0.001 , respectively.

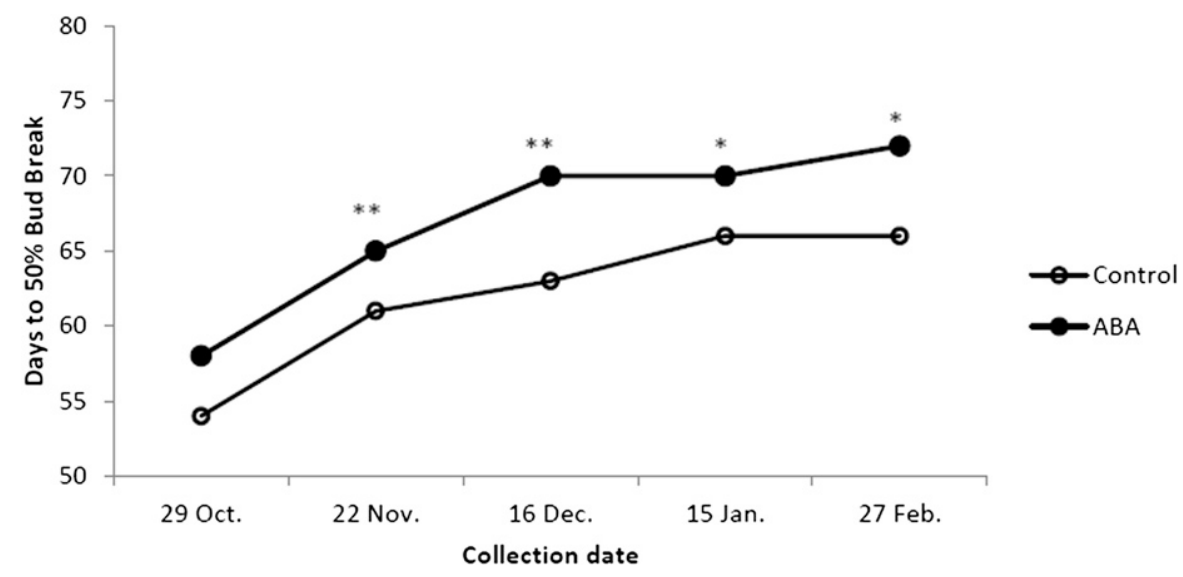

Fig. 3. Effect of abscisic acid (ABA) on bud dormancy (days to 50\% bud break) of 'Chambourcin' grapevines during the 2010-2011 season. For clarity, only one ABA plot was presented, which is the average of $4 \mathrm{~V}, 4 \mathrm{~V} 20,6 \mathrm{~V}$, and $6 \mathrm{~V} 20$ treatments. $4 \mathrm{~V}$ and $4 \mathrm{~V} 20$ correspond to ABA application of $400 \mathrm{mg} \cdot \mathrm{L}^{-1}$ at the $50 \%$ veraison stage and $20 \mathrm{~d}$ after the $50 \%$ veraison stage, respectively. $6 \mathrm{~V}$ and $6 \mathrm{~V} 20$ correspond to ABA application of 600 at the $50 \%$ veraison stage and $20 \mathrm{~d}$ after the $50 \%$ veraison stage, respectively. $* * *$, and $* * *$ indicate significance at $P \leq 0.05,0.01$, and 0.001 , respectively. as compared with those of control vines (Fig. 4A). Multiple applications did not increase the freezing tolerance on any collection date (data not shown).

During the 2010-11 dormant season, $\mathrm{LT}_{50} \mathrm{~s}$ were not different among treatments in Oct. 2010 (Fig. 4B). However, ABA treatment at the V and V20 stages consistently increased the freezing tolerance by an average of $3.5^{\circ} \mathrm{C}$. The freezing tolerance was also increased by ABA treatment at the V40 stage, but the effect was not consistent. There was no difference among treatments with ABA concentrations of 400 and $600 \mathrm{mg} \cdot \mathrm{L}^{-1}$. Additionally, it was observed in both years that $\mathrm{LT}_{50} \mathrm{~S}$ of ABA-treated vines decreased faster than those of untreated vines during the period from September through December, indicating that $\mathrm{ABA}$ treatment advanced cold acclimation in the fall. In other words, vines treated with $\mathrm{ABA}$ reached similar $\mathrm{LT}_{50}$ as in the control 3 weeks earlier (Fig. 4B). As a result of lack of availability of cane samples, $\mathrm{LT}_{50} \mathrm{~S}$ were not determined during the deacclimation stage in Year 2.

The assessment of bud death after exposure to $-19^{\circ} \mathrm{C}$ showed similar results to those obtained from $\mathrm{LT}_{50}$ determination. Bud death percent of ABA-treated vines (V and V20) and untreated vines was $11 \%$ and $15 \%$, respectively. Therefore, ABA treatment (V and V20) sustained less bud death, i.e., had a higher freezing tolerance than control. However, there was no difference among treatments with ABA concentrations of 400 and $600 \mathrm{mg} \cdot \mathrm{L}^{-1}$.

Bud water content. It was hypothesized that $\mathrm{ABA}$ increases freezing tolerance of buds by inducing bud tissue dehydration and hence leading to less freezable water. Water content averaged $55 \%$ and $80 \%$ in bud and leaf tissues and was not different among all treatment $24 \mathrm{~h}$ after ABA application. However, there was a progressive bud dehydration that took place in all treatments including control from Nov. 2010 to Feb. 2011 (Fig. 5). The dehydration process was enhanced by ABA treatment, specifically on $\mathrm{V}$ and V20 treatment (Fig. 5). The buds from ABA-treated vines (V and V20) started to show lower water content than those from control on 22 Nov. 2010, or $80 \mathrm{~d}$ after ABA application at the V20 stage (Fig. 5). The water content in buds from V and V20 treatments decreased on average by $20 \%$ as compared with that in control (Fig. 5). ABA treatment at the V40 stage also reduced bud water content, but not consistently. There was no difference among treatments with ABA concentrations of 400 and $600 \mathrm{mg} \cdot \mathrm{L}^{-1}$. To support the hypothesis about the relationship between ABA-induced freezing tolerance increase and dehydration, correlation analysis was conducted between freezing tolerance $\left(\mathrm{LT}_{50}\right)$ and water content in buds. A positive correlation $(R=0.342$, $P=0.001)$ between $\mathrm{LT}_{50}$ and water content was found, which indicated that decreased water content was associated with increased freezing tolerance (decreased $\mathrm{LT}_{50}$ ) and vice versa. 

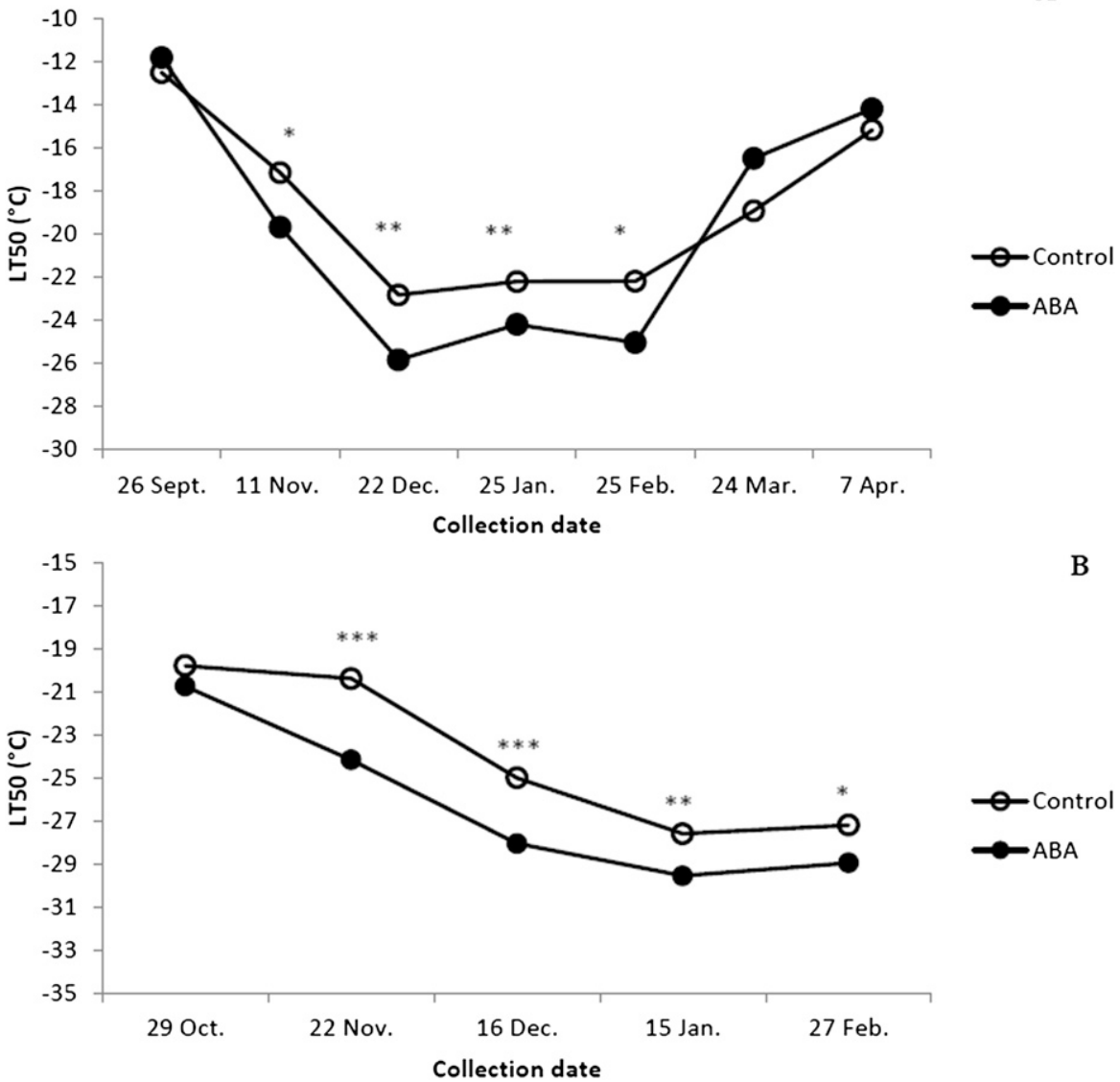

Fig. 4. Effect of abscisic acid (ABA) on freezing tolerance $\left(\mathrm{LT}_{50}\right)$ in 'Chambourcin' grapevines during the (A) 2009-2010 season and (B) 2010-2011 season. For clarity, only treatments with significant differences are shown. ABA plot is 4V30 in $\mathbf{A}$ and average of 4V, 4V20, 6V, and 6V20 in B. 4V, 4V20, and $4 \mathrm{~V} 30$ correspond to $\mathrm{ABA}$ application of $400 \mathrm{mg} \cdot \mathrm{L}^{-1}$ at the $50 \%$ veraison stage and 20 and $30 \mathrm{~d}$ after $50 \%$ the veraison stage, respectively. $6 \mathrm{~V}$ and $6 \mathrm{~V} 20$ correspond to $\mathrm{ABA}$ application of 600 at the $50 \%$ veraison stage and $20 \mathrm{~d}$ after the $50 \%$ veraison stage, respectively. $* * *$, and $* * *$ indicate significance at $P \leq 0.05,0.01$, and 0.001 , respectively.

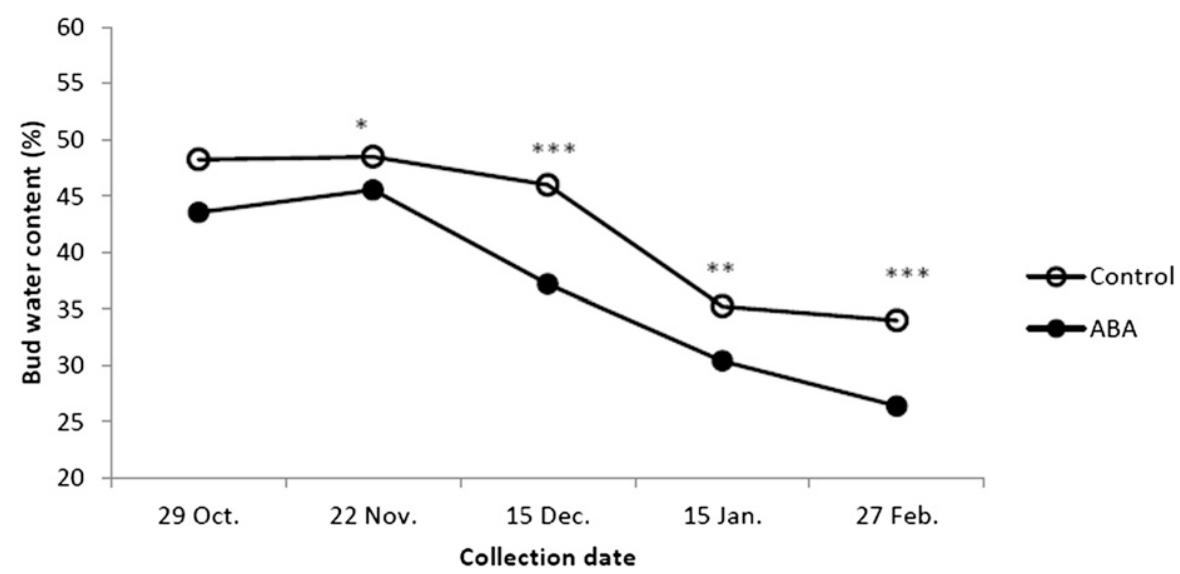

Fig. 5. Bud water content (percent fresh weight) progression in abscisic acid (ABA)-treated and untreated 'Chambourcin' grapevines during the 2010-2011 season. For clarity, ABA plot represents the average of $4 \mathrm{~V}, 4 \mathrm{~V} 20,6 \mathrm{~V}$, and $6 \mathrm{~V} 20 ; 4 \mathrm{~V}$ and $4 \mathrm{~V} 20$ correspond to ABA application of $400 \mathrm{mg} \cdot \mathrm{L}^{-1}$ at the $50 \%$ veraison stage and $20 \mathrm{~d}$ after the $50 \%$ veraison stage, respectively; $6 \mathrm{~V}$ and $6 \mathrm{~V} 20$ correspond to $\mathrm{ABA}$ application of 600 at the $50 \%$ veraison stage and $20 \mathrm{~d}$ after the $50 \%$ veraison stage, respectively. ${ }^{*}, * *$, and $* * *$ indicate significance at $P \leq 0.05,0.01$, and 0.001 , respectively.

\section{Discussion}

Based on this study, the highest ABA concentration with the least phytotoxicity for 'Chambourcin' grapevines should be less than $700 \mathrm{mg} \cdot \mathrm{L}^{-1}$. This result is similar to previous findings in a greenhouse study in which optimum concentration was between 400 and $600 \mathrm{mg} \cdot \mathrm{L}^{-1}$ (Zhang et al., 2011). Because ABA was applied at the $50 \%$ fruit set stage, a portion of flowers was present and thus were injured resulting in reduced berry number per cluster and loose clusters. ABA toxicity can be attributed to an oxidative damage induced by the overproduction of ABA-inducible reactive oxidative species (Jiang and Zhang, 2001). The small berries that remained green at harvest were likely the result of flower damage and insufficient fertilization caused by high $\mathrm{ABA}$ concentrations ( 700 and $\left.800 \mathrm{mg} \cdot \mathrm{L}^{-1}\right)$. Similar flower abscission has been reported with apple and pear trees when ABA was applied as a growth thinning agent between bloom and fruit set (Greene, 2009; Greene et al., 2011).

Compared with a greenhouse study, the phytotoxicity and shoot inhibition effect were reduced under field conditions. The damaged leaf area percent in the field was $25 \%$ lower than that in the greenhouse with the same ABA concentration $\left(800 \mathrm{mg} \cdot \mathrm{L}^{-1}\right)$. Additionally, shoot growth inhibition was only observed on grapevines treated with ABA concentration of $600 \mathrm{mg} \cdot \mathrm{L}^{-1}$ and above; whereas in the greenhouse, $\mathrm{ABA}$ treatment showed the effect at $200 \mathrm{mg} \cdot \mathrm{L}^{-1}$. The decreased ABA phytotoxicity under field conditions can be explained on the basis of leaf wax composition. It was reported that vines in the greenhouse have less cuticular wax than vines in the field because the former is typically well-watered (Bondada, 1996) and receive less ultraviolet radiation and light intensity (Gordon, 1998). Cuticular wax may reduce the efficiency of $\mathrm{ABA}$ penetration and absorbance.

In this study, the effects of ABA concentrations of 400 and $600 \mathrm{mg} \cdot \mathrm{L}^{-1}$ were not different. Therefore, the optimum ABA concentration with the least phytotoxicity and most economical was $400 \mathrm{mg} \cdot \mathrm{L}^{-1}$. In a similar field trial with 'Cabernet franc' grapevines, responses to $\mathrm{ABA}$ treatment of $600 \mathrm{mg} \cdot \mathrm{L}^{-1}$ were more consistent than those with $400 \mathrm{mg} \cdot \mathrm{L}^{-1}$ (Zhang and Dami, 2012). It is suggested that the optimum concentration of ABA is cultivar-dependent and should be determined first before further evaluations.

In this study, ABA did not affect yield components or basic juice chemical compositions of 'Chambourcin'. This result is consistent with previous findings on table grapes in which yield and fruit chemical compositions were unaffected by ABA treatment at $400 \mathrm{mg} \cdot \mathrm{L}^{-1}$ and higher (Lurie et al., 2009; Peppi et al., 2006, 2007). Because ABA was only sprayed on clusters at veraison stage, there was no report on leaf or flower damage from these studies.

The effect of ABA application on enhancing color development has been well documented. Research on table grapes showed that the expression of a key anthocyanin pathway gene was increased by exogenous ABA application, which promotes anthocyanin accumulation in berry skins (Peppi et al., 2008). It was also reported that the type of glucosides and anthocyanins that grapes contain had an influence on the effect of ABA 
treatment (Kim et al., 1998). In the ABA timing experiment, the enhancement of anthocyanin accumulation was observed in both years. The effective treatment was 4 Multiple and V20 (both 4V20 and 6V20) in 2009 and 2010, respectively. However, when applied during the $\mathrm{V}$ stage, ABA effect on color was not consistent, indicating the optimum timing for ABA application to enhance color development may be 3 weeks later than that in table grapes. It has been reported that on 'Cabernet Sauvignon', the most effective ABA applications were also those sprayed between $80 \%$ berry softening and $10 \mathrm{~d}$ after $100 \%$ berry softening (Gu et al., 2011). It is concluded that ABA application at the postveraison stage can enhance color development by promoting anthocyanin accumulation even when basic fruit composition (Brix, $\mathrm{pH}$, and TA) remains unchanged.

ABA also advanced periderm formation in field-grown 'Chambourcin'. In the field study, the leaf age of grapevines when applied ABA ranged between 70 and $130 \mathrm{~d}$ old since budburst. This finding is consistent with the greenhouse work in which it was reported that $\mathrm{ABA}$ induced periderm formation when applied on young (50 to $60 \mathrm{~d}$ ) and old (100 to 120 d) leaves (Zhang et al., 2011). The extent of periderm formation in 2010 was lower than that of 2009, which may be associated with the higher cropload in 2010 than that in 2009 . The average cropload of 2010 was $36 \%$ higher than that of 2009. Previous reports demonstrated that high cropload decreased periderm formation (Bates, 2008; Dami et al., 2005). It is noted that although clusters were thinned to the same level in both years, the cluster number in 2009 was lower than that of 2010 as a result of winter injury ( $86 \%$ primary bud death) recorded in Jan. 2009 (Dami et al., 2012). It is concluded that ABA application between fruit set and the post-veraison stage can enhance periderm formation of 'Chambourcin' grapevines.

The reduction of chlorophyll content occurred in mid-Sept. 2009 indicating a reduced photosynthesis activity and initiation of leaf senescence. Vines treated with ABA at the V30 stage (4V30 and 4Multiple, leaf age = 130 d) consistently had lower chlorophyll content compared with that of untreated vines. The significant difference was observed on 6 Oct. 2009, 1 week after ABA application. This result was similar to the findings in a previous greenhouse work, in which it was observed that a reduction of chlorophyll content occurred 2 weeks after ABA was applied to 120-d-old leaves and the leaf senescence process was advanced at the same time (Zhang et al., 2011). The role of ABA in leaf senescence was widely investigated in many plants and confirmed by both physiological and molecular evidences. It has been reported that the translocation of $\mathrm{ABA}$ from root to shoot triggered leaf abscission in cotton (Dong et al., 2008). Additionally, two senescence-associate mRNA, pSEN4, and pSEN5 were upregulated after exogenous ABA application in Arabidopsis thaliana, which demonstrated a linkage between ABA and leaf senescence (Park et al., 1998)

In this study, ABA treatments at $\mathrm{V}$ and V20 stages effectively advanced the bud dormancy process and when placed under forcing conditions, budburst was delayed as compared with that of the control. ABAinduced bud dormancy has been reported in other plants and a positive relationship between the concentration of endogenous ABA and dormancy has been demonstrated (Guak and Fuchigami, 2001; Or et al., 2000). ABA has been considered to play a positive role in dormancy induction and maintenance (Kucera et al., 2005). Therefore, under the forcing conditions used in the dormancy assay, D50BB ranged between 50 and 75 in both years, indicating that vines already entered endodormancy (Gu, 2003). The type of ABA-induced dormancy is considered endodormancy. This is further confirmed because single-node cuttings (not paradormancy, resulting from inhibition from other plant tissues) were used under favorable growing conditions (not ecodormancy, resulting from inhibition from the environment) (Lang et al., 1987). The results of field trials were consistent with greenhouse findings (Zhang et al., 2011).

It has been reported that exogenous ABA application can increase freezing tolerance of several plants such as Cicer arietinum L. (Kumar et al., 2008), Cacti family (Loik and Nobel, 1993), Secale cereal L. (Churchill et al., 1998), and Malus domestica (L.) Borkh (Guak and Fuchigami, 2001). In this study, ABA treatment at V20 and V30 stages consistently increased the freezing tolerance of buds during midwinter. There was no difference during the early cold acclimation (September and October) and deacclimation (March and April) stages. Additionally, it was demonstrated that there was a negative relationship between bud water content and freezing tolerance. Plant cells are usually dehydrated under an extracellular freezing process; and the dehydration-induced freezing tolerance has been well illustrated (Pearce, 2001). In grapes, it has been demonstrated that water stress in late fall can make grapevines acquire an early cold acclimation and dormancy, which can also be a consequence of the induction of ABA synthesis caused by water stress (Keller, 2010). It has been reported that an ABA-responsive protein kinase was involved with dehydration and cold acclimation in Triticum aestivum L. (Holappa and Walkersimmons, 1995).

In summary, foliar ABA application with an optimal concentration of $400 \mathrm{mg} \cdot \mathrm{L}^{-1}$ at 3 to 4 weeks postveraison was effective to induce cold acclimation and deep dormancy resulting in increased freezing tolerance of field-grown 'Chambourcin' grapevines. ABA treatment also increased anthocyanin content in berry skin without affecting yield components or basic juice chemical composition, which is a positive attribute for fruit and wine quality. It is concluded that exogenous ABA application can be considered as an additional protection tool against freezing stress of cold-sensitive grape cultivars grown in cold regions.

\section{Literature Cited}

Bates, T. 2008. Pruning level affects growth and yield of New York Concord on two training systems. Amer. J. Enol. Viticult. 59:276-286.

Bondada, B.R. 1996. Effect of water stress on the epicuticular wax composition and ultrastructure of cotton (Gossypium hirsutum L.) leaf, bract, and boll. Environ. Exp. Bot. 36:61.

Churchill, G.C., M.J.T. Reaney, S.R. Abrams, and L.V. Gusta. 1998. Effects of abscisic acid and abscisic acid analogs on the induction of freezing tolerance of winter rye (Secale cereale L.) seedlings. Plant Growth Regulat. 25:35-45.

Dami, I.E., S. Ennahli, and Y. Zhang. 2012 Assessment of winter injury in grape cultivars and pruning strategies following a freezing stress event. Amer. J. Enol. Viticult. 63: 106-111.

Dami, I., D. Ferree, S. Kurtural, and B. Taylor. 2005. Influence of crop load on 'Chambourcin' yield, fruit quality, and winter hardiness under midwestern United States environmental conditions. Proc. VII Intl. Symp. Grapevine Physiol. Biotechnol. Acta Hort. 689:203-208.

Dami, I., D. Ferree, A. Prajitna, and D. Scurlock. 2006. A five-year study on the effect of cluster thinning on yield and fruit composition of 'Chambourcin' grapevines. HortScience 41: 586-588.

Dong, H., Y. Niu, W. Li, and D. Zhang. 2008. Effects of cotton rootstock on endogenous cytokinins and abscisic acid in xylem sap and leaves in relation to leaf senescence. J. Expt. Bot. 59:1295-1304.

Eichhorn, K.W. and D.H. Lorenz. 1977. Phenological development stages of the grapevine. Nachrichtenbl. Dt. Pflanzenschutzd 29:119120.

Giusti, M., L. Rodriguez-Saona, and R. Wrolstad. 1999. Molar absorptivity and color characteristics of acylated and non-acylated pelargonidinbased anthocyanins. J. Agr. Food Chem. 47: 4631-4637.

Gordon, D.C. 1998. Effects of UV-B radiation on epicuticular wax production and chemical composition of four Picea species. New Phytol. 138:441-449.

Greene, D.W. 2009. Effect of abscisic acid on thinning and return bloom of Bartlett pears. HortScience 44:1128-1128.

Greene, D.W., J.R. Schupp, and H.E. Winzeler. 2011. Effect of abscisic acid and benzyladenine on fruit set and fruit quality of apples. HortScience 46:604-609.

$\mathrm{Gu}$, S. 2003. Rootstock and mounding effect on growth and freezing tolerance of 'Gewurztraminer' (Vitis vinifera) and bud dormancy of 'Lacrosse' and 'Chambourcin' (Vitis spp.). PhD diss., Univ. of Nebr., Lincoln, NE. Abstr. 3104616.

Gu, S., S. Jacobs, and G. Du. 2011. Efficacy, rate and timing of applications of abscisic acid to enhance fruit anthocyanin contents in 'Cabernet Sauvignon' grapes. J. Hort. Sci. Biotechnol. 86:505-510.

Guak, S. and L.H. Fuchigami. 2001. Effects of applied ABA on growth cessation, bud dormancy, cold acclimation, leaf senescence and $\mathrm{N}$ mobilization in apple nursery plants. J. Hort. Sci. Biotechnol. 76:459-464.

Hellman, E., S. Shelby, and C. Lowery. 2006. Exogenously applied abscisic acid did not consistently delay budburst of deacclimating grapevine. J. Amer. Pom. Soc. 60:178-186. 
Holappa, L. and M. Walkersimmons. 1995. The wheat abscisic acid-responsive protein-kinase messenger-RNA, pkaba1, is up-regulated by dehydration, cold temperature, and osmoticstress. Plant Physiol. 108:1203-1210.

Jeong, S.T., N. Goto-Yamamoto, S. Kobayashi, and A. Esaka. 2004. Effects of plant hormones and shading on the accumulation of anthocyanins and the expression of anthocyanin biosynthetic genes in grape berry skins. Plant Sci. 167:247-252.

Jiang, M.Y. and J.H. Zhang. 2001. Effect of abscisic acid on active oxygen species, antioxidative defence system and oxidative damage in leaves of maize seedlings. Plant Cell Physiol. 42:1265-1273.

Ju, Z. and L. Howard. 2003. Effects of solvent and temperature on pressurized liquid extraction of anthocyanins and total phenolics from dried red grape skin. J. Agr. Food Chem. 51:5207-5213.

Keller, M. 2010. The science of grapevines: Anatomy and physiology. 1st Ed. Academic Press, Burlington, MA.

Kim, S., J. Kim, S. Jeon, Y. Nam, and S. Kim. 1998. Effects of ethephon and ABA application on coloration, content, and composition of anthocyanin in grapes (Vitis spp.). J. Korean Soc. Hort. Sci. 39:547-554.

Kleinhenz, M., D. French, A. Gazula, and J. Scheerens. 2003. Variety, shading, and growth stage effects on pigment concentrations in lettuce grown under contrasting temperature regimens. HortTechnology 13:677-683.

Kucera, B., M.A. Cohn, and G. Leubner-Metzger. 2005. Plant hormone interactions during seed dormancy release and germination. Seed Sci. Res. 15:281-307.

Kumar, S., G. Kaur, and H. Nayyar. 2008. Exogenous application of abscisic acid improves cold tolerance in chickpea (Cicer arietinum L.). J. Agron. Crop Sci. 194:449-456.
Lang, G.A., J.D. Early, G.C. Martin, and R.L. Darnell. 1987. Endodormancy, paradormancy, and ecodormancy-Physiological terminology and classification for dormancy research. HortScience 22:371-377.

Llorente, F., J. Oliveros, J. Martinez-Zapater, and J. Salinas. 2000. A freezing-sensitive mutant of Arabidopsis, frs 1 , is a new aba3 allele. Planta 211:648-655.

Loik, M. and P. Nobel. 1993. Exogenous abscisicacid mimics cold-acclimation for Cacti differing in freezing tolerance. Plant Physiol. 103: 871-876.

Lurie, S., R. Ovadia, A. Nissim-Levi, M. OrenShamir, T. Kaplunov, Y. Zutahy, H. Weksler, and A. Lichter. 2009. Abscisic acid improves colour development in 'Crimson Seedless' grapes in the vineyard and on detached berries. J. Hort. Sci. Biotechnol. 84:639-644.

Naor, V., J. Kigel, Y. Ben-Tal, and M. Ziv. 2008 Variation in endogenous gibberellins, abscisic acid, and carbohydrate content during the growth cycle of colored Zantedeschia spp., a tuberous geophyte. J. Plant Growth Regul. 27:211-220.

Or, E., E. Belausov, I. Popilevsky, and Y. Ben Tal. 2000. Changes in endogenous ABA level in relation to the dormancy cycle in grapevines grown in a hot climate. J. Hort. Sci. Biotechnol. 75:190-194.

Pagter, M., C.R. Jensen, K.K. Petersen, F.L. Liu, and R. Arora. 2008. Changes in carbohydrates, $\mathrm{ABA}$ and bark proteins during seasonal cold acclimation and deacclimation in Hydrangea species differing in freezing tolerance. Physiol. Plant. 134:473-485.

Park, J.H., S.A. Oh, Y.H. Kim, H.R. Woo, and H.G. Nam. 1998. Differential expression of senescence-associated mRNAs during leaf senescence induced by different senescence-inducing factors in Arabidopsis. Plant Mol. Biol. 37:445-454.
Pearce, R. 2001. Plant freezing and damage. Ann. Bot. (Lond.) 87:417-424

Peppi, M.C., M.W. Fidelibus, and N. Dokoozlian. 2006. Abscisic acid application timing and concentration affect firmness, pigmentation, and color of 'Flame Seedless' grapes. HortScience 41:1440-1445.

Peppi, M.C., M.W. Fidelibus, and N.K. Dokoozlian. 2007. Application timing and concentration of abscisic acid affect the quality of 'Redglobe' grapes. J. Hort. Sci. Biotechnol. 82:304-310.

Peppi, M.C., M.A. Walker, and M.W. Fidelibus. 2008. Application of abscisic acid rapidly upregulated UFGT gene expression and improved color of grape berries. Vitis 47:11-14.

Read, P., S. Gu, S. Gamet, and J. Schild. 2004. Testing of varieties and selections tinder challenging climatic conditions. Proc. I Intl. Symp. Grapevine Growing, Commerce and Res. Acta Hort. 652:65-71.

Wake, C. and A. Fennell. 2000. Morphological, physiological and dormancy responses of three Vitis genotypes to short photoperiod. Physiol. Plant. 109:203-210.

Wolf, T.K. and R.M. Pool. 1987. Factors affecting exotherm detection in the differential thermalanalysis of grapevine dormant buds. J. Amer. Soc. Hort. Sci. 112:520-525.

Xiao, H., M. Siddiqua, S. Braybrook, and A. Nassuth. 2006. Three grape CBF/DREB1 genes respond to low temperature, drought and abscisic acid. Plant Cell Environ. 29:1410-1421.

Zhang, Y. and I. Dami. 2012. Foliar application of abscisic acid increases freezing tolerance of field-grown Vitis vinifera Cabernet franc grapevines. Amer. J. Enol. Viticult. 63:377-384.

Zhang, Y., T. Mechlin, and I. Dami. 2011. Foliar application of abscisic acid induces dormancy responses in greenhouse-grown grapevines. HortScience 46:1271-1277. 